\title{
A centromere-specific probe for fluorescence in situ hybridization on chromosomes of Apis mellifera $L$
}

\author{
M Beye, RFA Moritz * \\ Institut für Biologie, Technische Universität Berlin, Franklinstr 28/29, 10587 Berlin, Germany
}

(Received 13 September 1993; accepted 24 November 1993)

\begin{abstract}
Summary - Repetitive DNA was isolated through $\mathrm{CsCl}$ gradient centrifugation from genomic DNA of Apis mellifera L. DNA fragments were cloned and used for fluorescence in situ hybridization (FISH). Chromosomes were isolated from testes tissue of drone larvae. One clone, GC-6, proved to hybridize to the centromere of 14 chromosomes. This probe could be used in combination with others to identify various chromosomes of Apis mellifera.
\end{abstract}

Apis mellifera / chromosome / fluorescence in situ hybridization / repetitive DNA

\section{INTRODUCTION}

The chromosomal set of Apis mellifera $\mathrm{L}$ has been studied repeatedly. Since Petrunkewitsch's work (1901), we have known that it is comprised of 16 chromosomes. Although there were some claims that the karyotype should be only $n=8$ in A florea (Deodikar and Thakar, 1966), it is now widely accepted that a chromosome number of $n=16$ is the rule for other Apis species (Fahrenhorst, 1977; Milne, 1986). In spite of the relatively large body of studies on the karyotype of honeybees, we still have only limited knowledge on the identification of specific chromosomes. Sanderson and Hall (1948) found that one chromosome was larger than the rest of the set. This chro- mosome was also identified by Hoshiba and Kusangi (1978). They further claimed to have been able to identify all 16 chromosomes individually based on the various arm-length ratios, and observed 8 metacentric and 8 submeta/subtelocentric chromosomes. However, the literature shows that it is very difficult to accurately discriminate between chromosomes other than the large one (which is about twice the size of the others). In subsequent G- and C-banding work Hoshiba (1984) and Hoshiba and Okada (1986) reported different chromosome structures (4 metacentric and 12 submeta/subtelocentric chromosomes). Hoshiba (1984) attributed the differences from his previous results to different source tissue. However we believe that the interpretation of the published $\mathrm{G}$ - and $\mathrm{C}$-banding patterns

${ }^{*}$ Correspondence and reprints 
was also ambiguous. Even in the schematic presentation of the G-banding pattern diagram of $A$ mellifera (fig $3 b$ in Hoshiba and Okada, 1986), chromosomes 6 and 9, 10 and 11,12 and 13 , and 14 and 15 are absolutely identical. In the photographic reproductions of the metaphase chromosomes (Hoshiba and Okada, 1986) that were used to derive the schematic pattern, it is difficult to identify with certainty chromosomes other than chromosome 1.

Recent developments in in situ hybridization showed that DNA probes can be used to reveal the position of certain DNA regions on the chromosomes using fluorescent labeling (Pinkel et al, 1986). The technique of fluorescence in situ hybridization (FISH) has been successfully used by Beye and Moritz (1993) to identify the location of ribosomal RNA genes on 2 chromosomes of the honeybee using heterologous DNA probes from Drosophila melanogaster. Here we report on a probe isolated from repetitive honeybee DNA that specifically hybridizes close to the centromere of 14 chromosomes of the honeybee.

\section{METHODS}

\section{Probe-DNA isolation}

Total DNA was isolated from adult bees following the procedure of Beye and Raeder (1993). Total bee DNA $(200 \mu \mathrm{g})$ was fractionated by GC using a CsCl-bisbenzimide gradient in order to isolate the $27 \%$ GC fraction. The $27 \%$ GC satellite was partially restricted with EcoRi under standard conditions and DNA was cloned in $E$ coli using a pUC19 vector following standard protocols (Maniatis et al, 1989). Repetitive clones were identified by reverse genomic colony blot. Total bee DNA was labeled using the digoxigenin system (Boehringher Mannheim) and DNA was hybridized under standard conditions to the colony blots (Maniatis et al, 1989). Colonies containing repetitive bee DNA were identified on the blot by the strong intensity of their hybridization signals. Repetitive clones were nick-labeled with biotin using the Bio Nick System (GIBCO). One clone, GC-6, with a DNA insert of $2.7 \mathrm{~kb}$ was used as probe DNA for in situ hybridization.

\section{Chromosome preparation}

Testes were isolated from drone larvae ( $L 3-L 4$ ) taken from a colony of $A$ mellifera carnica. The tissue was placed in Grace's medium with 0.1 $\mu \mathrm{g} / \mathrm{ml} \mathrm{colcemid}$ and incubated at $37^{\circ} \mathrm{C}$ for 15 $\mathrm{min}$. The testes were resuspended in $1 \%$ sodium citrate and incubated for $15 \mathrm{~min}$ for tissue swelling. Metaphase chromosomes were obtained using the procedure of Fahrenhorst (1977) with a 3:1 (v/v) methanol/acetic acid fixation. In order to obtain plasma-free preparations, the fixation procedure was repeated 6 times at $0^{\circ} \mathrm{C}$. The further chromosome preparation, involving maceration with acetic acid, dehydration in ethanol, RNAse and pesin digestion and fixing, followed the protocol given by Beye and Moritz (1993).

\section{Fluorescence in situ hybridization and probe detection}

The hybridization protocol of Beye and Moritz (1993) was slightly modified. Probe DNA (4 $\mathrm{ng} / \mu \mathrm{l}$ ) and sheared herring sperm DNA $(1 \mu \mathrm{g} / \mu \mathrm{l})$ and tRNA from $E$ coli were dissolved in hybridization solution ( $50 \%$ formamide; $5 \%$ dextran sulfate; $2 \mathrm{x}$ SSC: $0.1 \mathrm{M} \mathrm{NaCl}, 0.03 \mathrm{M}$ sodium citrate) and added to the chromosome preparations. The slides were sealed with a cover slide and the DNA was denaturated $\left(80^{\circ} \mathrm{C}\right.$ for $\left.2 \mathrm{~min}\right)$ before hybridization at $35^{\circ} \mathrm{C}$ for $24 \mathrm{~h}$. The preparations were washed 3 times in $0.05 \times \mathrm{SSC}\left(42^{\circ} \mathrm{C}, 5 \mathrm{~min}\right)$ and twice in $2 \times$ SSC to remove unhybridized DNA, and were incubated $\left(15 \mathrm{~min}, 20^{\circ} \mathrm{C}\right)$ with blocking solution ( $2 \%$ bovine serum albumin in BT-buffer: $0.15 \mathrm{M} \mathrm{NaHCO}_{3} ; 0.05 \%$ Tween 20; $0.6 \mathrm{mM}$ sodium citrate; $\mathrm{pH} 8.0$ ). The samples were fluorescence-labeled following the protocol of Beye and Moritz (1993) and the labeled chromosome regions were visualized in an epifluorescence microscope using a $530 \mathrm{~nm}$ barrier and a $455 \mathrm{~nm}$ excitation filter. The DAPI staining was analyzed using unfiltered UV light. 


\section{RESULTS AND DISCUSSION}

The morphology of the chromosomal set (fig 1a) was different from the preparations made by Hoshiba and Kusangi (1978). Using DAPI staining, we could clearly locate the metacentric chromosome 1 , which is the largest one. The other chromosomes were mostly identified as submeta-, subtelo- or telocentric similar to the reports of Hoshiba (1984) who used G- and C-banding. He found 4 metacentric and 12 submeta/subtelocentric chromosomes.

The GC-6 probe was proved to hybridize close to the centromere of 14 chromosomes (fig 1b). The hybridization signal nicely

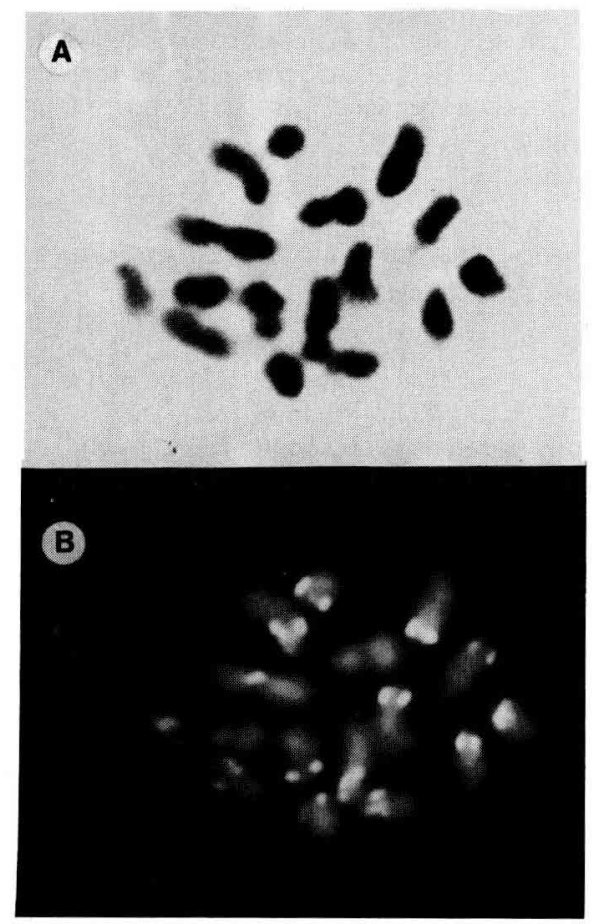

Fig 1. Reproduction of a DAPI-staining of the chromosomal set isolated from testes tissue of drone larvae. B. Same as in A but the fluorescence label of the hybridized GC-6 probe has been activated using a $530 \mathrm{~nm}$ barrier filter. reflects the double chromatid substructure in each chromosome since 2 homologous sites can be identified in each of the labeled chromosomes. Two chromosomes (one metacentric and one submetacentric) were not labeled with our DNA-probe. This may render it a helpful tool for individually characterizing the chromosomal set in combination with other probes. Clearly this probe alone is insufficient to characterize the indjvidual chromosomes. Nevertheless, only a few more markers may be necessary to conclusively identify each chromosome. Only 8 chromosomes cannot be discriminated by using the location of the hybridization signal on the chromosome (table I). Based on the present data, we can definitely discriminate 3 chromosomes: the large chromosome 1; and the metacentric unlabeled; and the submetacentric unlabeled chromosomes.

Other centromere-specific or pericentric probes have been isolated for a variety of species (Singer and Berg, 1991). Like GC6 , these probes are generally characterized by a high AT content and a repetitive sequence structure. This seems to be a typical feature of centromeric satellites. The DNA probe GC-6 seems to be extraordinary in that not all the chromosomes are labeled. In Drosophila melanogaster, for example, the simple sequences of satellites

Table I. Position of the centromere (2 unlabeled chromosomes) and location of the hybridization signal on the other 14 chromosomes using probe GC-6.

Signal Labeled Unlabeled

Metacentric Submetacentric Subtelocentric Telocentric

$\begin{array}{lr}1^{*} & 1 \\ 3 & 1 \\ 2 & - \\ 8 & -\end{array}$

* Chromosome No 1. 
I, II, and IV containing 5, 7 and 10 base-pair repeats hybridize to all the chromosomes. Only satellite III with a more complex structure hybridizes to the $X$ chromosomes (Lohe and Brutlag, 1986). Nevertheless, the hybridization of the GC- 6 probe to 14 out of 16 chromosomes may indicate that the sequence is an evolutionary old DNA fragment in the $A$ mellifera genome. Indeed such repetitive sequences proved useful for phylogenetic studies in Tribolium flour beetles (Juan et al, 1993) and it would be most intriguing to use this tool for the study of the evolution of the genus Apis.

\section{ACKNOWLEDGMENTS}

We wish to thank $\mathrm{J}$ Erber for providing access to the epifluorescence microscope and $\mathrm{H}$ Kaatz for helpful comments on an earlier version of the manuscript. The Deutsche Forschungsgemeinschaft granted financial support to RFAM.

\section{Résumé - Une sonde ADN spécifique} du centromère pour l'hybridation par fluorescence in situ sur des chromosomes d'Apis mellifera L. De l'ADN répétitif avec une teneur en $\mathrm{GC}$ de $27 \%$ a été isolé à l'aide d'un gradient de centrifugation au CsCl-bisbenzimide. L'ADN satellite a été partiellement restreint et cloné avec pUC19. Les clones renfermant I'ADN répétitif d'abeilles ont été isolés par la méthode d'hybridation sur colonies et utilisés comme sonde pour l'hybridation par fluorescence in situ (FISH). La préparation des chromosomes a été faite à partir des testicules de larves de mâles et la sonde ADN GC-6 hybridée à l'aide de la technique FISH aux endroits homologues sur le chromosome. La sonde ADN longue de 2,7 kb s'est révélée être spécifique du centromère (fig 1). Deux chromosomes, l'un métacentrique et l'autre submétacentrique, n'ont montré aucun signe d'hybridation. Le tableau I indique les types d'hybridation sur les 14 autres chromosomes. Trois chromosomes ont pu être définis de façon certaine. En combinaison avec d'autres sondes, il pourrait être possible de caractériser individuellement les autres chromosomes à l'aide de GC-6. Des sondes semblables ont déjà été trouvées chez Drosophila malanogaster et les coléoptères du genre Tribolium et utilisées entre autres pour des problèmes phylogénétiques. Cette méthode également pourrait être utilisée avantageusement pour étudier l'évolution au sein du genre Apis.

Apis mellifera / chromosome / ADN répétitif / hybridation in situ par fluorescence

\section{Zusammenfassung - Eine zentromer-} spezifische DNA-Sonde für die Fluoreszenz-in-situ-Hybridisierung auf Apis mellifera $\mathrm{L}$ Chromosomen. Repetetive DNA mit einem GC-Gehalt von $27 \%$ wurde über eine CsCl-bisbenzimid Gradientenzentrifugation isoliert. Die Satelliten-DNA wurde partiell restringiert und mit pUC19 kloniert. Klone mit repetetiver Bienen-DNA wurden mit Hilfe des Kolonie-Blot-Verfahrens isoliert und als Sonde für die Fluoreszenz-in-situ-Hybridisierung (FISH) eingesetzt. Chromosomenpräparate wurde von Drohnenlarven-Testes erstellt und die DNA-Sonde GC-6 mit Hilfe der FISH-Technik an homologe Stellen auf dem Chromosom hybridisiert. Die $2.7 \mathrm{~kb}$ lange DNA-Sonde erwies sich als zentromerspezifisch (Abb 1). Ein metazentrisches und ein submetazentrisches Chromosom zeigten kein Hybridisierungssignal. Tabelle I zeigt die Hybridisierungsorte auf den 14 anderen Chromosomen. Drei Chromosomen können mit dieser Technik eindeutig eingeordnet werden. In Kombination mit anderen Sonden sollte es möglich sein, mit Hilfe von GC-6 alle Chromosomen individuell zu charakterisieren. Ähnliche Sonden sind bereits bei Drosophila melanogaster und Tribolium Käfern gefunden worden und unter anderem auch für phylogenetische Fragestellungen eingesetzt worden. Es 
erscheint lohnend, die Methode auch für das Studium der Evolution innerhalb der Gattung Apis einzusetzen.

\section{Apis mellifera / Repetetive DNA / Chro- mosomen / Fluroreszenz-in situ-Hybri- disierung}

\section{REFERENCES}

Beye M, Moritz BFA (1993) In situ hybridization of rDNA on chromosomes of the honeybee, Apis mellifera $\mathrm{L}$. Experientia 49, 337-338

Beye M, Raeder U (1993) Rapid DNA preparation from bees and \% GC frationation. BioTechniques 14, 372 374

Deodikar GB, Thakar CV (1966) Cytogenetics of Indian honeybees and bearing on taxonomic and breeding problems. Ind J Genet 26 A, 286-393

Fahrenhorst $\mathrm{H}$ (1977) Chromosome number in the tropical honeybee species Apis dorsata and Apis florea. $\checkmark$ Apic Res 16, 56-58

Hoshiba $H$ (1984) Karyotype and banding analysis on haploid males of the honey bee (Apis mellifera). Proc Jpn Acad Ser B 60, 122-124
Hoshiba H, Kusangi A (1978) Karyological study of honeybee. J Apic Res 17, 105-109

Hoshiba H, Okada I (1986) G-banding analysis of male chromosomes in Apis cerana and Apis mellifera ligustica. Apidologie 17, 101-106

Juan C, Vazquez P, Rubio JM, Petitpierre E, Hewitt GM (1993) Presence of highly repetitive DNA sequences in Tribolium flour-beetles. Heredity 70, 1-8

Lohe AR, Brutlag DL (1986) Multiplicity of DNA sequences in Drosophila melanogaster. Proc Natl Acad Sci USA 83, 696-700

Maniatis T, Fritsch EF, Sambrook J (1989) Molecular Cloning: A Laboratory Manual. Cold Spring Habour Laboratory, NY, USA

Milne CP (1986) Cytology and cytogenetics. In: Bee Genetics and Breeding (TE Rinderer, ed). Academic Press, Orlando, FL, USA, 205-233

Petrunkewitsch A (1901) Die Richtungskörper und ihr Schicksal im befruchteten und unbefruchteten Bienenei. Zool Jahrb Abt Anat Ontog Tiere 14, 573608

Pinkel D, Straume T, Gray JW (1986) Cytogenetic analysis using quantitative, high-sensitivity, fluorescence hybridization. Proc Natl Acad Sci USA 83, 2934-2938

Sanderson AR, Hall DW (1948) The cytology of the honey bee Apis mellifera L. Nature (Lond) 162, 34-35

Singer M, Berg P (1991) Genes and Genomes. University Science Books, Mill Valley, CA, USA 